\title{
Assessing the Effects of Financial Heterogeneity in a Monetary Union : A DSGE Approach
}

\author{
Cristina Badarau and Grégory Levieuge
}

\section{LAREFI Working Paper CR11-EFI/08}

\section{1}

http://lare-efi.u-bordeaux4.fr

\author{
LAREFI
}

Université Montesquieu-Bordeaux IV

Bâtiment Recherche Economie

Avenue Léon Duguit - 33608 Pessac 


\begin{abstract}
:
The aim of this article is to analyze how financial heterogeneity can accentuate the cyclical divergences inside a monetary union that faces technological, monetary and financial shocks. To this purpose, this study relies on a two-country Dynamic Stochastic General Equilibrium model, where the two countries are supposed to be differently sensitive to the bank capital channel. The model allows us to demonstrate how a given symmetric shock causes cyclical divergences inside a heterogeneous monetary union. On this point, it allows reproducing some stylized facts recently observed in the UE. Moreover, it appears that the more heterogeneous the union, the larger the effects of financial asymmetries on the transmission of shocks. Finally, we show that a common monetary policy contributes to worsen cyclical divergences, in comparison with monetary policies that would be nationally conducted.
\end{abstract}

Key words: Financial Heterogeneity, Bank Capital Channel, DSGE Model, Euro Area.

JEL classification: E17, E32, E44, E52, C61 


\section{Introduction}

The structural heterogeneity inside the European Monetary Union is largely documented and commented ${ }^{1}$. Despite the attempts of convergence made by national governments, recent studies $^{2}$ have concluded that the financial system remains far from being integrated. More precisely, among the five main financial markets usually analyzed (money, government bond, corporate bond, banking credit and equity market), the banking markets appear as the most heterogeneous ${ }^{3}$.

As shown during the subprime mortgage crisis, banks widely contribute to the propagation of shocks, and in particular of financial ones, which have become recurrent over the last two decades (cf. the EMS crisis, the spillovers of the Asian financial crisis, the "dot-com bubble" boom and burst, etc.). In this perspective, several recent contributions ${ }^{4}$ have highlighted the relevance of the Bank Capital Channel (BCC), according to which banks' balance sheet structures may act as an amplifier for the transmission of shocks to the real economy. Theoretically, because of an agency problem between banks and their creditors, the formers bear an external financial premium that is negatively related to their capital ratio (and so is counter-cyclical).

The main issue is that this banks' external financing premium is ultimately passed on to the firms' credit conditions, what amplifies initial shocks. The Euro Area Lending Surveys published during the 2007-2008 period have underlined the tightening of credit standards for loans to firms following the previous financial shock. And this appears clearly as a consequence of the growing banks' costs of funds and their inability to access market financing. This confirms the existence of a BCC in Europe. But this channel is not homogeneous. Indeed, considering simultaneously the main factors underlying the BCC, an empirical study by Badarau-Semenescu \& Levieuge (2010) indicates that European countries are ought to be more (Germany, Italy, Netherland) or less (Finland, France, Spain) sensitive to this mechanism.

For these reasons, the BCC constitutes an interesting way to model the effects of financial heterogeneity in Europe. If empirical studies clearly report these financial asymmetries, theoretical models - in particular DSGE models - most often do not. Moreover, they pay no attention to the role of banks in propagating shocks ${ }^{5}$. It is then impossible to suitably 1)

\footnotetext{
${ }^{1}$ See for instance Jondeau \& Sahuc (2008), Sekkat \& Malek Mansour (2005), Angeloni \& Ehrmann (2007), Ekinci \& Al. (2007), Hofmann \& Remsperger (2005), Lane (2006).
}

${ }^{2}$ See Baele \& Al. (2004) and ECB (2008).

${ }^{3}$ Price differentials remain high, and home biases in lending to and borrowing of small non-financial corporations and households are persistent. National specificities in the firms' and banks' financial structures are documented for instance in Chatelain \& Al. (2003) or Ehrmann \& Al. (2003).

${ }^{4}$ For theoretical contributions see Blum \& Hellwig (1995), Chen (2001), Sunirand (2003), Van den Heuvel (2006), Gerali \& Al. (2008), Levieuge (2009a), Meh \& Moran (2010). To this respect Gertler \& Kiyotaki (2009) analyze the case of a capital quality shock to explain the role of financial intermediaries in the propagation of the recent crisis. For empirical evidence, see for instance Peek \& Al. (2000), Gambacorta \& Mistrulli (2004).

${ }^{5}$ See O. Issing (2006) for instance: "Can one really expect that models without an explicit, well developed financial sector can explain an economic world in which financial markets play an ever increasing role?". See also D. Khon (2008): "the macroeconomic models that have been used by 
understand and assess the effects of these structural asymmetries on cyclical divergences and 2) evaluate the macroeconomic policies that are likely to mitigate these effects.

In this empirical and theoretical context, the aim of this article is to develop a two-country DSGE model with four basic improvements regarding to the existing literature. First, referring to empirical evidence and responding to the deficiencies of standard DSGE models, we consider an explicit Bank Capital Channel, in a tractable but non-trivial way. Second, we consider that the two countries belong to a monetary union. Third, in line with empirical evidence, these two countries are supposed to be financially (structurally) heterogeneous ${ }^{6}$. Finally, we do not only consider monetary and technological shocks, but also financial ones.

All in all, these improvements allow a better understanding of the way financial heterogeneity accentuates the cyclical divergences between the members of a monetary union. Precisely, we demonstrate how a given symmetric shock causes cyclical divergences inside a heterogeneous monetary union. The model reproduces some stylized facts of the recent period. Moreover, we show that the more heterogeneous the union, the larger the effects of financial asymmetries on the transmission of shocks. Finally, it appears that a common monetary policy contributes to worsen the cyclical divergences. On these grounds, this contribution can be seen as a first step whose extensions would be the evaluation of monetary and budgetary policies that are likely to mitigate the effects of financial asymmetries. Again, the literature based on DSGE models usually neglects this question, for the more in a context of a two-country monetary union model.

The reminder of this paper is organized as follows. The second section describes the technical features of the baseline model, scrutinizing the partial (financial) and the general equilibriums. The third section exhibits the dynamics of the model and illustrates the adverse effects of the structural financial asymmetries in a monetary union. The fourth section demonstrates how a common monetary policy exacerbates these negative effects in such a context. The last section formulates some concluding remarks.

\section{The baseline model}

The model, based on Bernanke \& Al. (1999), Sunirand (2003) and Levieuge (2009a), describes a two-country monetary union with heterogeneous national banking structures. The main structure for each member country is depicted in appendix 1. Six categories of national agents act in each economy: households, entrepreneurs, retailers, capital producers, banks and a government. A common Central Bank is also considered.

Households supply labour and own the retail firms. They receive wages from entrepreneurs and profits from retailers, and use them for consumption and savings. Because the model

central banks to inform their monetary policy decisions are clearly inadequate. These models incorporate few, if any, complex relationships among financial institutions or the financialaccelerator effects and other credit interactions that are now causing stresses in financial markets to spill over to the real economy". Similar critics are founded in Bean (2009).

\footnotetext{
${ }^{6}$ Previous examples of monetary policy analysis in two-country models with different financial systems are provides by Faia (2002) or Gilchrist \& Al. (2002). The latter in particular settles for introducing asymmetric firms' balance sheet channels within a monetary union and analyzes the transmission of technological shocks. We extend their study considering the effects of a bank capital channel and different shocks.
} 
consists of a two-country monetary union, domestic households simultaneously consume domestic goods and goods produced in the other country of the union. They also pay lumpsum taxes to the Government, necessary to finance the public expenditures. Entrepreneurs (firms) use labor and capital as input (partially financed by debt) to produce wholesale final goods, in perfectly competitive markets. Retailers buy wholesale goods from the producers. They slightly differentiate them (with no costs) and retail them in a monopolistic competition market. CES aggregates of retail products are bought by households and by capital producers. The latter transform retail goods in capital (used by the entrepreneurs, in the production process).

A particular attention is paid to the banking markets, where the financial heterogeneity is considered. The role of banks is twofold in the model: on one hand, they participate as lenders to the firms. On the other hand, they collect funds from households (so as to insure the firms financing). The next subsections go into detail in the financial contracts describing the financial intermediation, before finally describing the aggregate relations of the DSGE model.

\subsection{The terms of the financial contracts between banks and entrepreneurs}

Be the case of a representative firm (entrepreneur) $i$. To produce wholesale final goods for the period $t+1$, the entrepreneur buys, at the end of the period $t$, the capital $K_{t+1}^{i}$ at a price $Q_{t}$. Because he cannot entirely self-finance the project, he uses his own net wealth $\left(N F_{t}^{i}\right)$, and borrows the remainder $\left(B_{t}^{i}\right)$ from a representative bank $j: B_{t}^{i}=Q_{t} K_{t+1}^{i}-N F_{t}^{i}$. The loan contracted has one period maturity. The expected return $\left(R_{t+1}^{i, K}=\omega_{t+1}^{i} R_{t+1}^{K}\right)$ of the representative firm $i$ is affected by an idiosyncratic ${ }^{7} \operatorname{risk}\left(\omega_{t+1}^{i}\right)$, whose realization is private information. Assuming a costly state verification framework à la Townsend (1979), bank $j$ needs to engage verification costs to reveal this information if the borrower declares bankruptcy. Following Bernanke \& Al. (1999), a predetermined threshold value of $\omega_{t+1}^{i}$, noted $\bar{\omega}_{t+1}^{i, F}$, exists such that:

$\bar{\omega}_{t+1}^{i, F} R_{t+1}^{K} Q_{t} K_{t+1}^{i}=R_{i, t+1}^{B} B_{t}^{i}$

(1), where

$R_{i, t+1}^{B}$ represents the non-default loan rate associated to the debt contract signed between the firm $i$ and the bank $j$. For $\bar{\omega}_{t+1}^{i, F}$ given, two possible situations exist: $\left.i\right) \omega_{t+1}^{i} \geq \bar{\omega}_{t+1}^{i, F}$, in which case the realized return of the firm is sufficiently high to repay its debt to the bank. The firm even obtains a benefit which is: $\left(\omega_{t+1}^{i}-\bar{\omega}_{t+1}^{i, F}\right) R_{t+1}^{K} Q_{t} K_{t+1}^{i}$; or ii) $\omega_{t+1}^{i}<\bar{\omega}_{t+1}^{i, F}$, in which case the firm revenues are insufficient to fulfill the loan contract, it declares bankruptcy and is liquidated. The auditing cost the bank has to spend if the firm declares bankruptcy $\left(\mu^{B} \omega_{t+1}^{i} R_{t+1}^{K} Q_{t} K_{t+1}^{i}\right)$ is supposed to be proportional to the gross return on the firm's

\footnotetext{
${ }^{7} \omega_{t+1}^{i}$ is a random variable that follows a log-normal distribution of mean $-\sigma^{2} / 2$ and standard deviation $\sigma$, independent and identically distributed among firms and in time. It fulfills all general conditions for the existence of the financial contract. See Bernanke \& Al. (1999), Sunirand (2003) or Levieuge (2009b) for example.
} 
investment, where $\mu^{B}$ is the factor of proportionality. The bank thus only receives $\left(1-\mu^{B}\right) \omega_{t+1}^{i} R_{t+1}^{K} Q_{t} K_{t+1}^{i}$, after the verification procedure.

But at the same time the banker must collect funds from households to finance the entrepreneur. Thus, he must implicitly consider the cost of such operations. Banks operate in a perfectly competitive environment, are neutral to the idiosyncratic risk and to the aggregate risk associated to the banking activity, but adverse to the aggregate risk associated to the entrepreneurs' activity ${ }^{8}$. In the seminal model of Bernanke \& Al. (1999), the banks' portfolios are infinitely large, and the idiosyncratic risk $\omega^{i}$ is completely diversified.

Households are thus sure to benefit from a riskless return when they lend to banks, and the financing cost for banks does not depend on their capital structure. But, a more realistic assumption is that banks' loan portfolios are of finite size. The risk associated with the firms' investment projects is thus partly transferred to banks (which can now default), and ultimately to households. By analogy with the bank-firm relation, the return on the loans portfolio of the bank is supposed to be private information. A creditor household has to engage a costly state procedure to observe the return of the bank to which he has lent funds, if the bank declares bankruptcy. A second agency problem then arises, now between banks (borrower) and households (lender), whose treatment will render the external financing costly for banks and will oblige them to accumulate inside capital. Like in Krasa \& Villamil (1992), households perform the role of 'monitoring the monitors'.

To maintain the model tractability at the aggregate level, we follow hereafter Sunirand (2003) when supposing that a bank can only participate to the investment projects of one firm $^{9}$. In such a way, the idiosyncratic risk is fully diversified at the aggregate level, but not at the bank level. This assumption also allows to simplify hereafter the notations, by renouncing to indices $i$ and $j$.

In such a context, at the period $t$, the representative bank uses its inside accumulated capital $\left(N B_{t}\right)$ and other complementary funds raised from households $A_{t}=Q_{t} K_{t+1}-N F_{t}-N B_{t}$ to lend $B_{t}=Q_{t} K_{t+1}-N F_{t}$ to a representative firm. According to the aforementioned assumptions, the risk of the firm $\left(\omega_{t+1}\right)$ is directly transferred to the bank's balance sheet. Let's denote by $R_{t+1}^{A}$ the non-default gross return on bank securities subscribed by the household. The threshold value of $\omega_{t+1}$ that describes the default of the bank $\left(\bar{\omega}_{t+1}^{B}\right)$ must thus satisfy the relation:

$\left(1-\mu^{B}\right) \bar{\omega}_{t+1}^{B} Q_{t} R_{t+1}^{K} K_{t+1}=R_{t+1}^{A} A_{t}$

The left-hand-side of the relation (2) corresponds to the gain obtained by the banker from financing the entrepreneur, in the bad scenario, when the firm goes bankruptcy and the bank pays the monitoring cost $\left(\mu^{B}\right)$. The right-hand-side of (2) gives the amount of the banker's pledge towards the household. As in Sunirand (2003), the threshold value for the bank's bankruptcy is always lower than the threshold value calculated for the firm's

${ }^{8} \mathrm{As} R_{i, t+1}^{B}$ is predetermined, all shocks affecting the aggregate component $R_{t+1}^{K}$ are borne only by firms.

${ }^{9}$ As discussed in Sunirand (2003), with the assumption of a finite size for the banks' loan portfolios, the aggregation should depend on the distribution of risky projects in each bank. An equivalent situation occurs when supposing that one bank can lend to several firms, but the return on the firms' investment projects is perfectly correlated within a bank, while it is i.i.d across banks. 
default $\left(\bar{\omega}_{t+1}^{F}>\bar{\omega}_{t+1}^{B}\right)$. The banks default is always conditional to the previous default of firms. But the defaulting of a firm does not necessarily imply that its bank goes bankrupt. If, after the costly verification procedure, the banks can recuperate sufficient funds to pay the households, they can survive. Three situations are thus possible: i) $\omega_{t+1}>\bar{\omega}_{t+1}^{F}>\bar{\omega}_{t+1}^{B}$, in which case there is no default and the financial contract runs without any difficulty; ii) $\bar{\omega}_{t+1}^{F}>\omega_{t+1}>\bar{\omega}_{t+1}^{B}$, in which case only the entrepreneur goes bankrupt, while the banker receives sufficient funds after the monitoring procedure to pay the creditor household; and iii) $\bar{\omega}_{t+1}^{F}>\bar{\omega}_{t+1}^{B}>\omega_{t+1}$, when entrepreneur and bank declare default, and the household starts a costly verification of the banker, whose cost $\left(\mu^{A}\right)$ is proportional to the bank's gross return: $\mu^{A}\left(1-\mu^{B}\right) \omega_{t+1} Q_{t} R_{t+1}^{K} K_{t+1}$, with $\mu^{A}>\mu^{B}{ }^{10}$

In this context, the terms of the contract between the bank and the entrepreneur come from the resolution of an optimization program that seeks to maximize the entrepreneur's expected benefits, subject to the participation condition for the bank, and implicitly to that for the household ${ }^{11}$. The solutions of this program give the firm demand for capital and the value of the thresholds $\bar{\omega}_{t+1}^{F}$ and $\bar{\omega}_{t+1}^{B}$. The non-default loan rate associated to the contract between the entrepreneur and the bank $\left(R_{t+1}^{B}\right)$ is then easily obtained from (1), and the gross return to be paid to the household $\left(R_{t+1}^{A}\right)$ comes from (2). The first order conditions of the program lead to the following external finance premium for the firm, as solution to the agency problem ${ }^{12}$ :

$S_{t}^{F}=\Psi_{F}\left[k_{t+1}^{F}\right]$, where $S_{t}^{F}=E_{t}\left[\frac{R_{t+1}^{K}}{R_{t+1}^{f}}\right], \frac{\partial \Psi_{F}(\cdot)}{\partial k_{t+1}^{F}}>0$ and $k_{t+1}^{F}=\frac{Q_{t} K_{t+1}}{N F_{t}+N B_{t}}$

In a logarithmic form, $S_{t}^{F}$ simply defines the firm's external finance premium in the model, $\mathrm{i}$. e. the difference between the net return on the firm's physical capital required by the bank $\left(r_{t+1}^{K}=R_{t+1}^{K}-1\right)$ and the risk-free rate $\left(r_{t+1}^{f}=R_{t+1}^{f}-1\right)$.

Unlike Bernanke \& Al. (1999), the firm's external finance premium does not only depend on the firm's financial position $\left(\frac{Q_{t} K_{t+1}}{N F_{t}}\right)$, but also on the accumulated inside capital of the bank $\left(N B_{t}\right)$. All things being equal, the lower the firm's net wealth $\left(N F_{t}\right)$, the higher the cost of its external financing. Moreover, it depends on the bank's financial situation. As $S_{t}^{F}$ negatively depends on $N B_{t}$ in (3), the lending interest rate required by a badcapitalized bank is ought to be higher than that charged by a healthier one. This fact clearly shows the internalization by the entrepreneurs of the banks' external financing costs. So much so that a deterioration in banks' balance sheet finally implies a tightening of the lending conditions to firms. This is the bank capital channel manifestation, previously discussed.

\footnotetext{
${ }^{10}$ The monitoring procedure is more costly for households than for banks (which are specialized in this kind of operations). This justifies the intermediation activity by banks.

${ }^{11}$ As discussed hereafter in the description of the DSGE model, the participation constraints of the different agents to the financial contract refer to the opportunity cost given by the risk-free rate.

${ }^{12}$ Details on the explicit form of the optimization program and its solution are available in the separate Technical Appendix.
} 


\subsection{The terms of the financial contracts between banks and households}

Contracting with firms, the banks also interact with households to collect funds. Households are neutral to the idiosyncratic risk, but averse to the aggregate risk ${ }^{13}$. They elaborate their gain expectations on the basis of the average (aggregate) return of banks in the economy $\left(R_{t+1}^{B}\right)$. As previously, the lender (household) knows that the return of the borrower (bank) is subject to an idiosyncratic (and not spontaneously observable) risk ${ }^{14}$, noted $\varepsilon_{t+1}$, supposed to follow a log-normal distribution similar to that of $\omega_{t+1}$. Precisely, a threshold $\bar{\varepsilon}_{t+1}$ exists for the banker, under which he goes bankrupt. This threshold value satisfies the condition:

$\bar{\varepsilon}_{t+1} R_{t+1}^{B} B_{t}=R_{t+1}^{A} A_{t}$

(4), where

$R_{t+1}^{A}$ is the non-default gross return to be paid by the bank on the funds raised from household at the end of period $t$. So, if $\varepsilon_{t+1} \geq \bar{\varepsilon}_{t+1}$, the bank's revenues are sufficient to fulfill its commitments towards the household. On the contrary, if $\varepsilon_{t+1}<\bar{\varepsilon}_{t+1}$, the bank declares bankruptcy. But the realization of $\varepsilon_{t+1}$ is private information. In case of bankruptcy announcement, the household has to pay an auditing $\operatorname{cost}\left(\mu^{A} \varepsilon_{t+1} R_{t+1}^{B} B_{t}\right)$ proportional to the gross return of the bank's loans portfolio to obtain the real value of $\varepsilon_{t+1}$. He thus recovers: $\left(1-\mu^{A}\right) \varepsilon_{t+1} R_{t+1}^{B} B_{t}$.

The terms of the financial contract between the bank and a representative household are simply obtained by maximizing the expected bank's benefit, subject to the household participation constraint. The solution of the program allows determining $B_{t}$ and the threshold value $\bar{\varepsilon}_{t+1}$, in function of the realizations of $R_{t+1}^{B}$. The solution of this agency problem gives rise to an external finance premium for the banker, defined by ${ }^{15}$ :

$S_{t}^{B}=\Psi_{B}\left[k_{t+1}^{B}\right]$, where $S_{t}^{B}=\frac{R_{t+1}^{B}}{R_{t+1}^{f}}, \frac{\partial \Psi_{B}(\cdot)}{\partial k_{t+1}^{B}}>0$ and with $k_{t+1}^{B}=\frac{B_{t}}{N B_{t}}$

As expected, the non-default return on the bank's loans portfolio required by the household $\left(R_{t+1}^{B}\right)$ is higher than the risk-free interest rate. The spread only depends on the bank's financial leverage, defined here by the accumulated inside capital on loans ratio.

The relations (3) and (5) clearly show that the cost of external finance for firms/banks depend on the accumulated net worth of the agents $(N F$ and $N B$ ). The firm's net worth mainly comes from the accumulated benefits, i.d. the accumulated value of the firm $\left(V F_{t}\right)$. In addition, it is

\footnotetext{
${ }^{13}$ It means that the aggregate risk will be borne by firms and banks. The mechanism which protects households from the aggregate risk is the following. The non-default interest rate on bank securities are predetermined at the end of period $t$. So, if in $t+1$, the effective return on non-idiosyncratic component of firms' or banks' investments is lower than expected, households will be compensated with the higher non-default interest rate on bank securities.

${ }^{14}$ In other words, not only a defaulting entrepreneur can drag a bank down with him, as we have seen in the previous subsection, but also a bank can declare bankruptcy because of an adverse idiosyncratic shock.

${ }^{15}$ Details on the explicit form of the optimization program and its solution are available in the separate Technical Appendix. See also Levieuge (2009b).
} 
assumed that the entrepreneur offers its labour force ${ }^{16}$ and perceives a wage $\left(W F_{t}\right)$, which increases the firm's net wealth, so that:

$N F_{t}=\gamma^{F}\left[V F_{t}+W F_{t}\right]$

where the coefficient $\gamma^{F}$ corresponds to the survival probability of the firm, assuming that a constant proportion $\left(1-\gamma^{F}\right)$ of firms leave the market each period. When living the market, the remaining net wealth is entirely used to consume final goods $\left(C F_{t}\right)$ :

$C F_{t}=\left(1-\gamma^{F}\right)\left[V F_{t}+W F_{t}\right]=\frac{1-\gamma^{F}}{\gamma^{F}} N F_{t}$

Besides, the value of the firm $\left(V F_{t}\right)$ is given by the gross return on capital, after the repayment of the debt and of the associated interests. So, for $S_{t-1}^{F}$ given in (3):

$V F_{t}=Q_{t-1} R_{t}^{K} K_{t}-S_{t-1}^{F} R_{t}^{f} B_{t-1}$

In a similar way, the bank inside capital comes mainly from the accumulated benefits of the intermediation activity, i.d. the intrinsic value of the bank $\left(V B_{t}\right)$. Besides, it is assumed that a proportion $\left(1-\gamma^{B}\right)$ of banks leaves the market each period, transferring a small part $\left(t^{B}\right)$ of their inside capital to new banks ${ }^{17}$ (for an aggregated amount $T_{t}^{B}$ ). Then, for $S_{t-1}^{B}$ given in (5), banks' net wealth can be written:

$N B_{t}=\gamma^{B} V B_{t}+T_{t}^{B}$

with $\quad V B_{t}=R_{t}^{K} B_{t-1}-S_{t-1}^{B} R_{t}^{f} A_{t-1}$

(10),

The outgoing banks, once their transfers to newcomers done, consume in final goods their remaining capital:

$C B_{t}=\left(1-\gamma^{B}\right)\left(1-t^{B}\right) V B_{t}=\frac{\left(1-\gamma^{B}\right)\left(1-t^{B}\right)}{\gamma^{B}\left(1-t^{B}\right)+t^{B}} N B_{t}$

\subsection{The general equilibrium model}

With a Cobb-Douglas constant return to scale technology for firms and an equivalent condition to define the banks' activity, the individual equations (3) and (5) to (11) remain unchanged after aggregation ${ }^{18}$. The partial equilibriums solved for the financial markets are then easily embedded in a dynamic general equilibrium model of a two-country monetary union. Apart from the financial imperfections, the model is standard. Each country is inhabited by a continuum of infinitely-lived households represented by the unit interval.

\footnotetext{
${ }^{16}$ This assumption just allows the wholesale producers to borrow immediately; otherwise, they should face an unrealistically high external finance premium.

${ }^{17}$ In line with other financial accelerator models, this assumption gives the possibility to new banks to benefit from initial capital, which is essential for the access to external financing. Without initial wealth, the external financial premium would be prohibitive for newcomers.
}

${ }^{18}$ See Bernanke \& Al. (1999) or Sunirand (2003) for more details on the aggregation procedure. 
These agents choose consumption $(C)$ and leisure $(L)$ and determine the working time $(H=1-L)$ remunerated at a real rate $W$. The one period utility function is given by:

$U\left(C_{t}, H_{t}\right)=\frac{\sigma_{c}}{\sigma_{c}-1} C_{t}^{\frac{\sigma_{c}-1}{\sigma_{c}}}-\frac{\sigma_{h}}{\sigma_{h}+1} H_{t}^{\frac{\sigma_{h}+1}{\sigma_{h}}}$

$\sigma_{c}$ the consumption intertemporal elasticity of substitution, and $\sigma_{h}$ the elasticity of the disutility associated to labour.

Consumption is a composite index which depends on the consumption of goods domestically produced and goods produced in the other country of the union. The origin of goods is indexed by 1 and 2, while $C$ and $C^{*}$ denote aggregate consumption in the first and the second country of the union, respectively. $\gamma \in[0,1]$ represents the relative preference for consumption of domestic produced goods, in each country.

$$
C=\frac{C_{1}^{\gamma} C_{2}^{1-\gamma}}{\gamma^{\gamma}(1-\gamma)^{1-\gamma}} ; C^{*}=\frac{\left(C_{1}^{*}\right)^{1-\gamma}\left(C_{2}^{*}\right)^{\gamma}}{\gamma^{\gamma}(1-\gamma)^{1-\gamma}}
$$

Price indexes for the two countries are respectively: $P=P_{1}^{\gamma} P_{2}^{1-\gamma}$ and $P^{*}=\left(P_{2}\right)^{\gamma}\left(P_{1}\right)^{1-\gamma}$, and the law of one price is supposed to hold.

Households choose a sequence of consumption, labour, bank securities $\left(A_{t}\right)$ and other possible financial investment $\left(D_{t}\right)$ at the real risk-free interest rate, which maximizes an intertemporal utility function, based on (12), subject to the following budget constraint:

$$
P_{t} C_{t}+P_{t} D_{t}+A_{t} \leq P_{t} W_{t} H_{t}+A_{t-1} R_{t}^{A}+P_{t} D_{t-1} R_{t}^{f}-T_{t}+\Pi_{t}
$$

In (14), $R_{t}^{A}=1+r_{t}^{A}$ and $R_{t}^{f}=1+r_{t+1}^{f}$ denote respectively the gross returns of the two alternative financial investments for households, $T_{t}$ represents lump sum taxes and $\Pi_{t}$ are the dividends received from the ownership of retail firms. Symmetric constraint applies in the second country of the union, and the first order conditions associated to $C_{t}, D_{t}, A_{t}$ and $H_{t}$ appear in the following table:

Table 1. First order conditions for the households' optimization

\begin{tabular}{|l|l|}
\hline Country 1 & Country 2 \\
$\lambda_{t}=\frac{1}{P_{t}} C_{t}^{-\frac{1}{\sigma_{c}}}$ & $\lambda_{t}^{*}=\frac{1}{P_{t}^{*}}\left(C_{t}^{*}\right)^{-\frac{1}{\sigma_{c}}}$ \\
$0=\lambda_{t}-\beta R_{t+1}^{f} E_{t}\left[\lambda_{t+1}\right] E_{t}\left[\frac{P_{t+1}}{P_{t}}\right]$ & $0=\lambda_{t}^{*}-\beta R_{t+1}^{f^{*}} E_{t}\left[\lambda_{t+1}^{*}\right] E_{t}\left[\frac{P_{t+1}^{*}}{P_{t}^{*}}\right]$ \\
$0=\lambda_{t}-\beta R_{t+1}^{A} E_{t}\left[\lambda_{t+1}\right]$ & $0=\lambda_{t}^{*}-\beta R_{t+1}^{A^{*}} E_{t}\left[\lambda_{t+1}^{*}\right]$ \\
$H_{t}=\left(\lambda_{t} P_{t} W_{t}\right)^{\sigma_{h}}$ & $H_{t}^{*}=\left(\lambda_{t}^{*} P_{t}^{*} W_{t}^{*}\right)^{\sigma_{h}}$ \\
\hline
\end{tabular}

The following condition is fulfilled at the optimum: $\left(R_{t+1}^{f}\right) E_{t}\left[\frac{P_{t+1}}{P_{t}}\right]=\left(R_{t+1}^{f^{*}}\right) E_{t}\left[\frac{P_{t+1}^{*}}{P_{t}^{*}}\right]$, corresponding to the equality of the real interest rates inside the union. This allows writing: 
$\Theta_{t}=\frac{P_{t}^{*}}{P_{t}}$ is an expression of the bilateral terms of trade.

Wholesale producers combine labour and capital with a Cobb-Douglas constant return to scale technology:

$Y_{t}=a_{t} K_{t}^{\alpha} L_{t}^{1-\alpha}$ and $Y_{t}^{*}=a_{t}^{*}\left(K_{t}^{*}\right)^{\alpha}\left(L_{t}^{*}\right)^{1-\alpha}$

(16), with

$a_{t}$ an exogenous productivity factor that follows a standard autoregressive process in the model: $a_{t}=\rho_{a} a_{t-1}+\varepsilon_{a}$, where $\varepsilon_{a}$ defines a productivity shock, with zero mean and unit variance. The labour imput in (16) is a composite index of households labour $\left(H_{t}\right)$ and entrepreneurial labour $\left(H_{t}^{F}\right): L_{t}=H_{t}^{\Omega}\left(H_{t}^{F}\right)^{1-\Omega}$. As indicated previously, entrepreneurs supplement their income by supplying their labour force, remunerated at a rate $W^{F}$. Note that the total entrepreneurial labour is normalized to unity. In each country, the investment $\left(I_{t}\right)$ is supposed to concern domestic produced goods. The accumulation of physical capital is introduced by the standard equation, with $\delta$ the depreciation rate:

$$
K_{t+1}=(1-\delta) K_{t}+I_{t}
$$

It is also assumed that there are some internal capital adjustment costs $\Phi(\cdot)$ introduced by the presence of the capital producers, who buy $I_{t}$ units of final goods and transform them in physical capital sold to the entrepreneurs.

$\Phi\left(I_{t}, K_{t}\right)=\frac{\phi}{2}\left(\frac{I_{t}}{K_{t}}-\delta\right)^{2} K_{t}$, for $\phi>0$

Noting $\rho_{t}=\frac{P_{1, t}^{\omega}}{P_{1, t}}$ the relative price of wholesale goods produced in the country $1, Q_{t}$ the Lagrange multiplier associated to the process of capital accumulation, and given the term of trade $\frac{P_{1}}{P_{2}}=\frac{P_{t}^{*}}{P_{t}}=\Theta_{t}$, the profit maximization program of domestic firms gives the first order conditions (relative to $H_{t}, H_{t}^{F}, I_{t}$ and $K_{t+1}$ respectively), reported in table 2.

Table 2. First order conditions for firms' optimization

\begin{tabular}{|l|}
\hline Country 1 1*) \\
$\rho_{t}\left(\Theta_{t}\right)^{1-\gamma} \Omega(1-\alpha) \frac{Y_{t}}{H_{t}}=W_{t} \quad ; \quad \rho_{t}\left(\Theta_{t}\right)^{1-\gamma}(1-\Omega)(1-\alpha) \frac{Y_{t}}{H_{t}^{F}}=W_{t}^{F} \quad ; \quad Q_{t}=1+\frac{\partial \Phi(\cdot)}{\partial I_{t}} ;$ \\
$E_{t}\left[R_{t+1}^{K}\right]=\frac{1}{Q_{t}} E_{t}\left[\rho_{t+1}\left(\Theta_{t+1}\right)^{1-\gamma} \alpha \frac{Y_{t+1}}{K_{t+1}}-\frac{\phi}{2}\left(\delta^{2}-\left(\frac{I_{t+1}}{K_{t+1}}\right)^{2}\right)+(1-\delta) Q_{t+1}\right]$
\end{tabular}

(*) For the second country of the union the first order conditions are symmetric, except for the exponent of $\Theta_{t}$, which becomes $(\gamma-1)$ instead of $(1-\gamma)$.

As in Levieuge (2009a) the profit maximization of capital producers is internalized in this program. The first two conditions define the labour demands. The third gives the Tobin's $Q$ ratio. The last relation represents the expected gross return to holding a unity of capital from 
$t$ to $t+1$. At the optimum, the firms' demand for capital insures the equality between the expected marginal cost for the external financing and the expected marginal return on capital. Retailers are represented by firms, held by households, which purchase wholesale goods and retail them afterwards. Their main role is to differentiate final goods. In so doing, they allow introducing price inertia in the model. Following Calvo (1983), it is assumed that a retailer changes his price with probability $1-\varsigma$, in a given period. Subsequently, the retailer pricing behavior leads to the following 'new Phillips curves' in the two countries of the union:

$\hat{\pi}_{1, t}=\beta E_{t}\left[\hat{\pi}_{1, t+1}\right]+\kappa \hat{\rho}_{t}$ and $\hat{\pi}_{2, t}=\beta E_{t}\left[\hat{\pi}_{2, t+1}\right]+\kappa \hat{\rho}_{t}^{*}$

(19), where $\pi_{1, t}=\log \left(P_{1, t} / P_{1, t-1}\right)$ and $\pi_{2, t}=\log \left(P_{2, t} / P_{2, t-1}\right)$ give the inflation rates calculated in the domestically priced goods for the two countries, $\kappa=\frac{(1-\varsigma)(1-\varsigma \beta)}{\varsigma}$ and $\rho_{t}, \rho_{t}^{*}$ are respectively the real marginal cost for a representative retailer in each country. $\hat{x}_{t}$ defines, for all $x_{t}$, the deviation of a variable $x_{t}$ from its steady-state value.

The national goods and labour markets equilibrium conditions imply:

$$
\begin{aligned}
& Y_{t}=\Theta_{t}{ }^{\frac{1-\gamma}{2 \gamma-1}} C_{t}\left[\gamma+(1-\gamma) \Theta_{t}^{1-\sigma_{c}}\right]+I_{t}+G_{t}+C F_{t}+C B_{t} \\
& Y_{t}^{*}=\left(\Theta_{t}\right)^{\frac{\gamma}{1-2 \gamma}+\sigma_{c}} C_{t}^{*}\left[(1-\gamma)+\Theta_{t}{ }^{1-\sigma_{c}} \gamma\right]+I_{t}^{*}+G_{t}^{*}+C F_{t}^{*}+C B_{t}^{*}
\end{aligned}
$$

and respectively:

$$
\begin{aligned}
& \left(H_{t}\right)^{\frac{\sigma_{h}+1}{\sigma_{h}}}=\left(C_{t}\right)^{-\frac{1}{\sigma_{c}}} \rho_{t}\left(\Theta_{t}\right)^{1-\gamma} \Omega(1-\alpha) Y_{t} \\
& \left(H_{t}^{*}\right)^{\frac{\sigma_{h}+1}{\sigma_{h}}}=\left(C_{t}^{*}\right)^{-\frac{1}{\sigma_{c}}} \rho_{t}^{*}\left(\Theta_{t}\right)^{\gamma-1} \Omega(1-\alpha) Y_{t}^{*}
\end{aligned}
$$

National governments use lump-sum taxes to finance public expenditures, which follow standard autoregressive process:

$$
\begin{aligned}
& \hat{g}_{t}=\rho_{g} \hat{g}_{t-1}+\varepsilon_{g_{t}} \\
& \hat{g}_{t}^{*}=\rho_{g}^{*} \hat{g}_{t-1}^{*}+\varepsilon_{g_{t}}^{*}
\end{aligned}
$$

$\rho_{g}, \rho_{g}^{*}<1$, and $\varepsilon_{g_{t}}, \varepsilon_{g_{t}}^{*}$ are random budgetary shocks with zero mean and unit standard deviation.

Finally, the common Central Bank conducts the monetary policy following a standard monetary policy rule (with respect to the union-wide inflation):

$\hat{r}_{t}^{n}=\beta_{0} \hat{r}_{t-1}^{n}+\left(1-\beta_{0}\right) \beta_{1} \hat{\pi}_{t}^{U M}+\varepsilon_{r_{t}}$ (23), where $\hat{\pi}_{t}^{U M}=\frac{1}{2}\left(\hat{\pi}_{t}+\hat{\pi}_{t}^{*}\right)$. The $\beta_{1}>0$ coefficient corresponds to the reaction of the monetary policy to the union-wide inflation deviation from its steady-state level. $\beta_{0} \in[0 ; 1[$ is the smoothing coefficient of the nominal interest rate. $\varepsilon_{r_{t}}$ represents a monetary policy shock.

A financial shock is added to this model - as well as technological, budgetary and monetary shocks that are introduced in equations (16), (22) and (23) respectively. In previous equations, $Q_{t}$ represents the fundamental value of the firms' physical capital, given by the 
actualized amount of dividends to be obtained by the firms' shareholders. We now allow for the possibility that the market value of the capital, denoted hereafter by $Q_{t}^{m}$, differ temporarily from its fundamental value $Q_{t}$, because of a temporary financial shocks $\left(\varepsilon_{q_{t}}\right)$ :

$Q_{t}^{m}=Q_{t}+\varepsilon_{q_{t}}$

with $\varepsilon_{q_{t}}$ a random variable of zero average. If the shock arises in $t$, it affects the market value $Q_{t}^{m}$ of the capital only at this period; afterwards, starting from the $t+1$ period, the equality between $Q_{t}^{m}$ and $Q_{t}$ holds again ${ }^{19}$. Hence, in case of financial shock, the fundamental return on the physical capital given in Table 2 becomes an abnormal return on capital given by:

$$
R_{t}^{K m}=\frac{\rho_{t}\left(\Theta_{t}\right)^{1-\gamma} \alpha \frac{Y_{t}}{K_{t}}-\frac{\phi}{2}\left(\delta^{2}-\left(\frac{I_{t}}{K_{t}}\right)^{2}\right)+(1-\delta) Q_{t}^{m}}{Q_{t-1}}
$$

Then, $Q_{t}^{m}$ replaces $Q_{t}$ in the equations (3), (4), (5) and (8), respectively defining the dynamics of firms' net worth, banks' net worth, and the subsequent external finance premiums. So, when $Q_{t}^{m}>Q_{t}$, the firms' and banks' net values increase without any fundamental justification. The seeming improvement of their balance sheet allows them to obtain better conditions for external financing, stimulating the national investment and output (and inversely in case of adverse financial shock).

\subsection{The model parameterization}

The calibration for the parameters and the variables (or ratios) at their steady-state is made according to the references found in the literature for the euro area. Ratios such as capital/GDP, investment/GDP or total consumption/GDP are all compatible with the estimations revealed by Fagan \& Al. (2001). Moreover, it is realistically supposed that banks have a lower default probability than firms, and that the ratio $\frac{N B}{B}$ belongs to the interval $[0.1,0.2] \cdot{ }^{20}$ Finally, the probability for a bank to leave the credit market is lower than for firms, and as already evoked, the audit is more costly for households than for banks. The calibration for the baseline model is detailed in appendix 3.

\section{Financial asymmetries and transmission of shocks inside the union}

In line with empirical evidence, financial structural heterogeneity is now introduced in the model, by assuming that the banks financial leverage at their steady-state and the sensibility coefficient of the banks' external finance premium to their financial structure $\left(\psi_{B}^{s}\right)$ are not

\footnotetext{
${ }^{19}$ Then, the financial shock corresponds to a one-period financial bubble, whereas Bernanke \& Gertler (1999) and Levieuge (2009a) simulate an exogenous multi-period one. The aim here is not to reproduce the effects of a long-lasting financial bubble, but simply to adequately insert financial shocks in the model.

${ }^{20}$ See, for example, the numerical values used by Sunirand (2003) and Levieuge (2009a) for the euro area.
} 
similar in the two countries. We then analyze the sensitivity of the national dynamics to the degree of the union's financial heterogeneity.

\subsection{Transmission of shocks and dynamics of the model}

We assume that the banking system in country 2 is better capitalized than in country 1 ( $\frac{N B^{*}}{B^{*}}=0.2>0.15=\frac{N B}{B}$ in the baseline parameterization). Moreover, country 1 is characterized by an external finance premium for banks that is more sensitive to changes in their leverage, compared to country $2^{21}$. Concretely, $\psi_{B}^{S}=0.002$ and $\psi_{B}^{S^{*}}=0.001$ are chosen for the baseline calibration. To concentrate on the asymmetric effects only due to the bank capital channel, we consider that both countries are identical in the firm-side. So, besides the symmetrical financial accelerator related to the firms' financial situation, we expect to obtain an additional and asymmetrical financial accelerator due to the banking sectors heterogeneity.

This is verified in the Figure 1, which represents the dynamics ${ }^{22}$ of the two countries of the union following an unexpected fall in the market value of the physical capital $\left(Q_{m}\right)$. This shock negatively affects the agents' net worth, their financial position and the external finance premium they must bear.

\footnotetext{
${ }^{21}$ Technically, a lower capitalization ratio at the steady state endogenously implies higher monitoring costs. As these costs contribute to the definition of an external financial premium in this CSV framework, assuming simultaneously a lower capitalization and a higher elasticity to banks' leverage to characterize the most affected country is logical.

${ }^{22}$ Simulations are implemented with Dynare. See Adjemian \& Al. (2009). Note that the BlanchardKahn conditions are satisfied; the model has a unique and stable trajectory to its steady state. Note also that an unexpected rise in the nominal interest rate gives conventional results.
} 
Figure 1.Impulse response functions to a negative financial shock
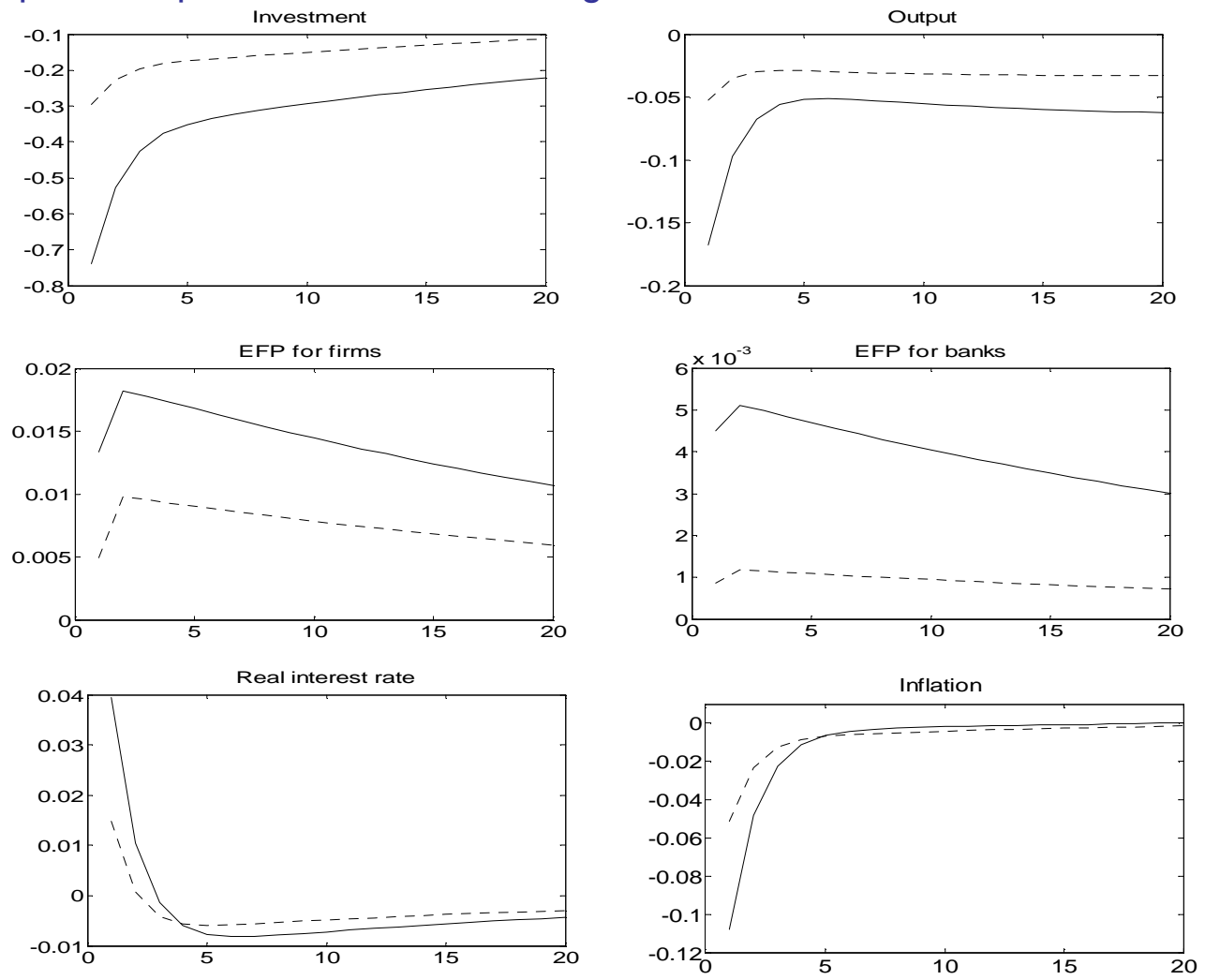

Country 1 is -- Country 2 : Weak bank capital channel $\left(N B / B=0.2 ; \psi_{B}^{s}=0.001\right)$

more affected $\longrightarrow$ Country 1: High bank capital channel $\left(N B / B=0.15 ; \psi_{B}^{s}=0.002\right)$

than country 2 .

Two factors contribute to these dissimilar national adjustments. First, national banks face higher external finance premium in country 1 because of their deeper financial fragility and because of the higher sensitivity to their balance sheet structure. The cost of the firms' external finance is subsequently higher, reducing the incentive to invest and the aggregate demand in turn. As a result, inflation falls more in country 1 . Second, as the Central Bank reduces the common nominal interest rate accordingly to the average inflation rate, the real interest rate increases more in country 1 than in country 2 . In the absence of union, the national Central Bank of the country 1 would have cut its policy rate more than a common Central Bank (with average objectives) would have done. This reinforces the adverse macroeconomic effects of the initial shock (section 4 goes into detail on this point). Subsequently, the investment drop is more than $100 \%$ higher in country 1 , and inflation and output divergences are important within the union. As a rule, the national divergences are large despite the low calibrated values for the elasticity of banks' finance premium to their respective balance sheet structures. The (heterogeneous) bank capital channel is then potentially very powerful.

This theoretical simulation matches the recently observed pattern of financial and macroeconomic variables in the EA. According to Badarau-Semenescu \& Levieuge 
(2010), Italy is typically ought to be more sensitive ${ }^{23}$ to the BCC than France (i.e. Italy would be the country 1 and France the country 2). Precisely, the figures in appendix 2, in line with the figure 1, show that French and Italian lending rates to firms have spread away starting autumn 2007. Moreover, while output and investment have similarly evolved in both countries before the year 2007, they have clearly diverged since. In the light of the theoretical simulations, the financial asymmetries (and more precisely the differences in bank capital channel strength) can explain the diverging cyclical evolution of European countries in the wave of the financial crisis.

The next subsection demonstrates that the more heterogeneous the union is, the larger the effect of financial asymmetries on the transmission of shocks.

\subsection{Sensitivity of the economies to the degree of financial heterogeneity}

Two sources of financial asymmetries are successively analyzed, following a negative financial shock.

First, the figure 2 illustrates the sensitivity of the economies to differences in terms of national banking systems leverage. While the elasticity coefficient for the banks' external finance $\left(\psi_{B}^{s}\right)$ is fixed to 0.002 for the two countries, the national banking systems leverage take the value 0.1 for country 1 , and varies within the interval $[0.1,0.2]$ for country 2 .

Second, the figure 3 illustrates the increasing divergences implied by growing differences in terms of elasticity of the finance premium for banks to their financial structure. It is now assumed that the $\frac{N B}{B}$ ratios are identical and equal to 0.15 in the two countries, while $\psi_{B}^{s}$ is fixed to 0.001 for country 2, and varies within the interval $[0.001,0.003]$ for country 1 . Differentials are represented in absolute value. Once again, a higher heterogeneity in the sensitivity of the national banks' premiums to their balance sheet structure is associated to more asymmetric transmission of the financial shock inside the union, and to higher macroeconomic divergences among member countries.

\footnotetext{
${ }^{23}$ What is confirmed by Gambacorta \& Mistrulli (2004).
} 
Figure 2. Impact of the banking system leverage asymmetry on the model dynamics
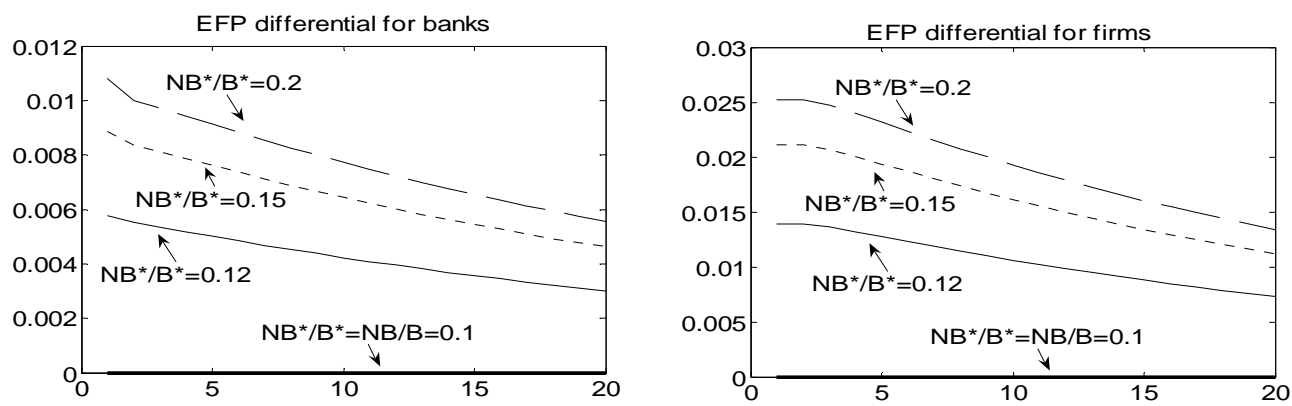

Inflation and output divergences in the union

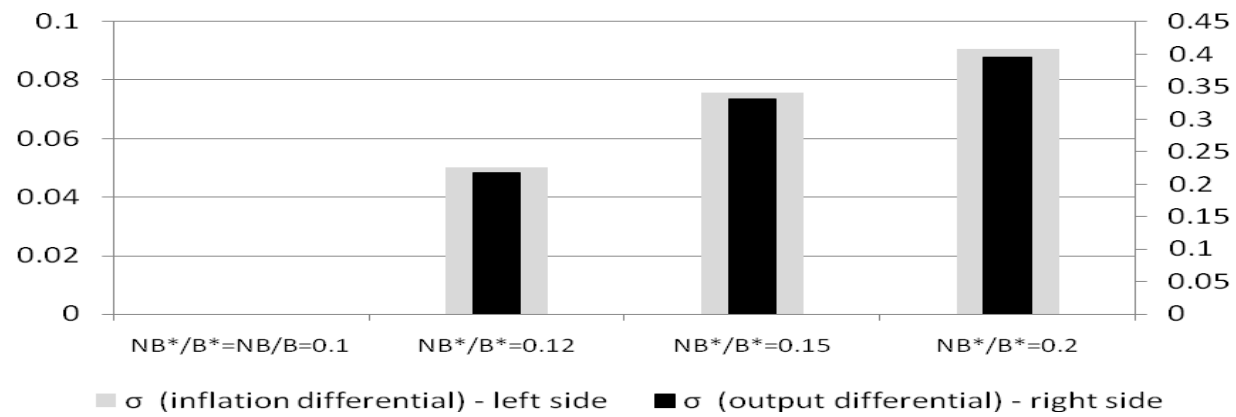

Figure 3. Impact of the sensitivity coefficients heterogeneity on the model dynamics
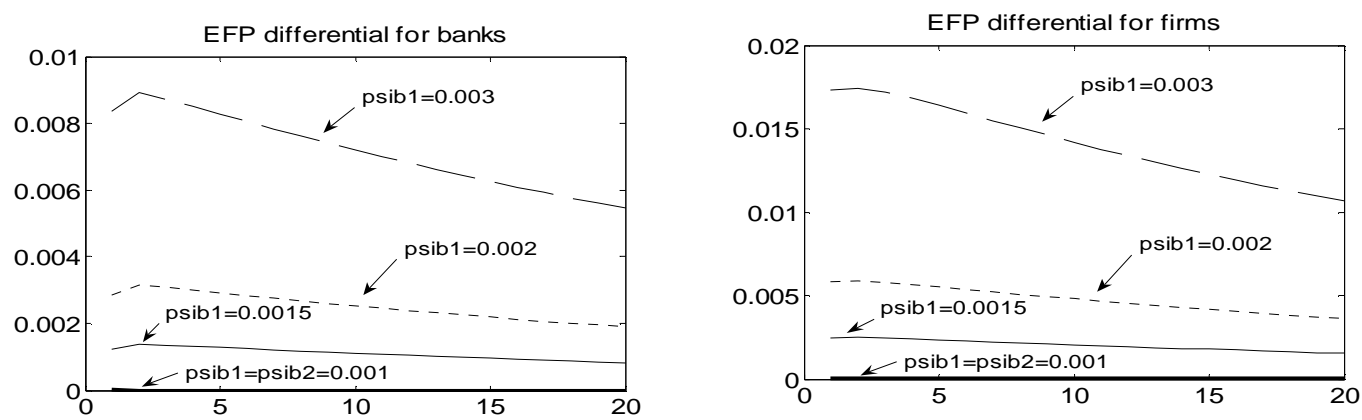

Inflation and output divergences in the union

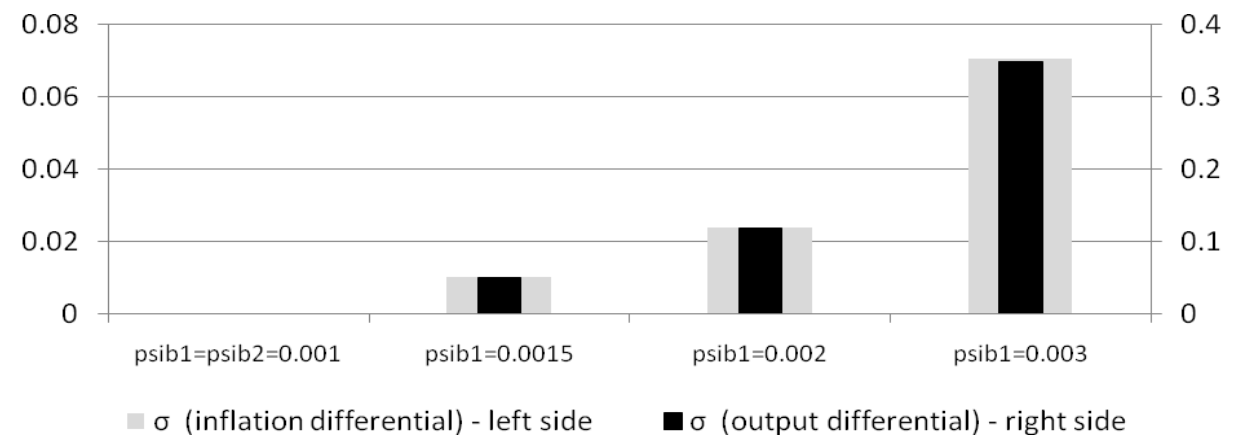




\section{The costs of a heterogeneous monetary union}

As briefly evoked previously, it can be demonstrated that the conduct of a single monetary policy for the (financially asymmetric) union as a whole worsens the cyclical divergences. When considering a symmetric monetary shock in the baseline model, preliminary simulations indicate that the reaction of the output of the country 1 (stronger affected by the bank capital channel) is instantly $60 \%$ higher than in country 2 . In contrast, if each country were supposed to conduct autonomously its monetary policy, the output response in the country 1 would be only $20 \%$ higher than in country $2 .{ }^{24}$ In other words, a common monetary policy in an asymmetric union implies a stabilization bias.

Figure 4 illustrates the rationale for this stabilization bias in a context of negative and symmetric financial shock.

\section{Figure 4. Macroeconomic divergences with common vs national monetary policies}
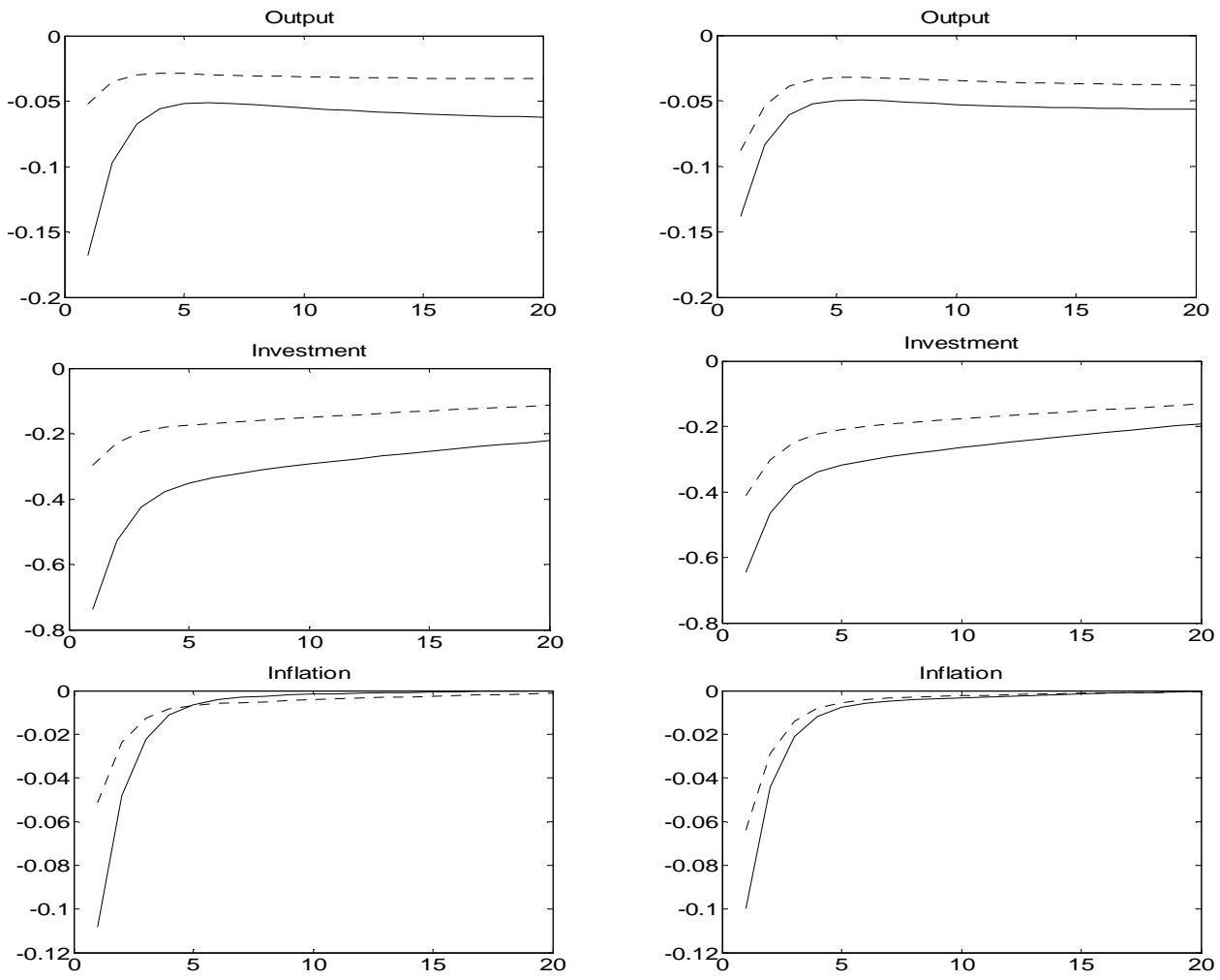

Common monetary policy

Country 2: weak bank capital channel

_ Country 1: high bank capital channel
National monetary policy

Country 2: weak bank capital channel

- Country 1: high bank capital channel

${ }^{24}$ The model then provides results that are quantitatively in accordance with Sunirand (2003) and Levieuge (2009a) for a single country. 
As a common monetary policy seeks to stabilize the average inflation of the whole area, the interest rate cut is more important in the union than what a national monetary policy would imply for country 2 (which is by definition less sensitive to shocks). Subsequently, this economy benefits from lower real interest rates, which mitigates its decrease in investment and output, and immunizes it to shocks as a whole. On the contrary, for symmetrical reasons, the participation to the asymmetric monetary union implies more adverse reactions to shocks (compared to a national conduct of monetary policy) for the country with a stronger bank capital channel. Thus, a single monetary policy that only reacts to average variables of an asymmetric union worsens the cyclical divergences among member countries.

\section{Conclusion}

The aim of this paper was to offer a general theoretical framework suited to analyze the effects of the financial heterogeneity inside a monetary union, paying attention to the bank capital channel (which has generated great interest for several years), and to financial shocks (which are now recurrent). This has led us to build a two-country DSGE model, calibrated in reference to previous studies for the euro area. This model generates conventional dynamics, but with deeper amplification of shocks, because of the effects of the financial accelerator and the bank capital channel. Simulations indicate that structural and precisely financial asymmetries lead to striking cyclical divergences among members of the Union. This is true in case of financial shocks, what illustrates the diverging individual responses of European countries following the subprime mortgage crisis. To this respect, it is shown that the more financially heterogeneous the Union is, the larger the cyclical divergences. Moreover, the conduct of a single monetary policy for the Union as a whole seriously worsens these national divergences.

These results call for an analysis of the macroeconomic policies that could mitigate the effects of financial heterogeneity. The on-going extensions of this model allow us to investigate whether the monetary policy should rely on the national dispersion of inflation, and how national budgetary policies should be combined. 


\section{References}

Adjemian, S., Juillard, M., Mihoubi, F., Perendia, G. \& S. Villemot (2009), "Dynare Manual: version 4.0.4", Cepremap.

Angeloni, I. \& M. Ehrmann (2007), "Euro area inflation differentials", The B.E. Journal of Macroeconomics, 7(1), Art. 24, Berkeley Electronic Press.

Badarau-Semenescu, C. \& G. Levieuge (2010), "Assessing the potential strength of the Bank Capital Channel in Europe: A Principal Components Analysis", The Review of Finance and Banking, vol. 2(1), 5-16, June.

Baele, L., Ferrando, A., Hordahl, P., Krylova E. \& C. Monnet (2004), 'Measuring financial integration in the Euro area', European Central Bank, Occasional Paper series, No. 14/April 2004.

Bean C. (2009), "The Great Moderation, the Great Panic and the Great Contraction", Speech in Bank of England, $25^{\text {th }}$ August.

Bernanke, B., Gertler, M. \& S. Gilchrist (1999), "The financial accelerator in a quantitative business cycle framework", in "Handbook of Macroeconomics" (Taylor J.B. \& M. Woodford), Vol. 1, North-Holland.

Blum, J. \& Hellwig, M. (1995), "The Macroeconomic Implications of Capital Adequacy Requirements for Banks", European Economic Review, 39, 739-749.

Calvo, G.A. (1983), "Staggered prices in a utility-maximizing framework", Journal of Monetary Economics, 12, 383-398.

Chatelain, J-B., Ehrmann, M., Generale, A., Martinez-Pages, J., Vermeulen, P. \& A. Worms (2003), "Monetary policy transmission in the Euro Area: new evidence from micro data on firms and banks", Journal of the European Economic Association, MIT Press, 1 (2-3), 731742.

Chen, N.K. (2001), "Bank net worth, asset prices and economic activity", Journal of Monetary Economics, 48, 415-36.

ECB (2008), ECB Monthly Bulletin, March 2008.

Ehrmann, M, Gambacorta, L, Martinez-Pages, J, Sevestre, P and Worms, A (2003), "Financial systems and the role of banks in monetary policy transmission in the euro area', in "Monetary policy transmission in the euro area: A Study by the Eurosystem Monetary Transmission Network" (Angeloni, I, Kashyap, A and Mojon, B), Cambridge University Press, 235-269.

Ekinci, M. F., Kalemi-Ozcan, S. \& B. E. Sorensen (2007), "Financial integration within the EU countries: The role of institutions, confidence and trust", Second Symposium of the ECB-CFS Research Network on Capital Markets and Financial Integration in Europe, 13 14 february 2008, Frankfurt am Main.

Fagan, G., Henry, J. \& R. Mestre (2001), "An Area-Wide Model (AWM) for the Euro Area", ECB Working Paper No. 42.

Faia, E. (2002), "Monetary Policy in a world with different financial systems", EBC Working Paper No. 183.

Gambacorta L. \& P.E. Mistrulli (2004), "Does Bank Capital Affect Lending Behavior?", Journal of Financial Intermediation, 13, 436-457.

Gerali, A., Neri, S., Sessa, L. \& F.M. Signoretti (2008), "Credit and Banking in a DSGE Model”, ECB Conference on Financial Markets and Macroeconomic Stability, 15-16 Dee. 2008, Frankfurt am Main.

Gertler, M. \& N. Kiyotaki (2009), "Financial Intermediation and Credit Policy in Business Cycle Analysis", in Handbook of Monetary Economics, Vol.3, ed. B. Friedman \& M. Woodford, North-Holland. 
Gilchrist, S., Hairault, J-O. \& H. Kempf (2002), "Monetary policy and the financial accelerator in a monetary union", ECB Working Paper No. 175.

Hofmann, B. \& H. Remsperger (2005), "Inflation differentials among the Euro area countries: Potential causes and consequences", Journal of Asian Economics, 16 (2005), 403-419.

Issing O. (2006), "The ECB's Monetary Policy Strategy: Why did we choose a Two Pillar Approach?", $4^{\text {th }}$ ECB Central Banking Conference on 'Money and Monetary Policy in the $21^{\text {th }}$ Century, $10^{\text {th }}$ November.

Jondeau, E. \& J. G. Sahuc (2008), "Testing heterogeneity within the Euro Area", Economics Letters, 99, 192-196.

Kohn, D. (2008), "Productivity and Innovation in Financial Services", Speech at the Official Celebration of the 10th Anniversary of the Banque Centrale du Luxembourg.

Krasa, S. \& A.P. Villamil (1992), "Monitoring the monitor: an incentive structure for a financial intermediary", Journal of Economic Theory, 57, 197-221.

Lane, P.R. (2006), "The real Effects of the Euro", Journal of Economic Perspectives, 20(4), 47-66.

Levieuge G. (2009a), “The Bank Capital Channel and Counter-Cyclical Prudential Regulation in a DSGE model", Louvain Economic Review, 75(4).

Levieuge G. (2009b), "Annexes détaillées de l'article 'The Bank Capital Channel and Counter-Cyclical Prudential Regulation in a DSGE model'", LEO Working Paper, 2009-02.

Meh, C. and K. Moran. (2010) "The Role of Bank Capital in the Propagation of Shocks." Journal of Economic Dynamics and Control, 34, 555-76.

Peek, J., Rosengren, E. \& Tootell, G. (2000), "Identifying the Macroeconomic Effect of Loan Supply Shocks", Federal Reserve of Bolton Working Paper, No. 2.

Sekkat, Kh. \& J. Malek Mansour (2005), "Exchange rate fluctuations, trade and asymmetric shocks in the Economic and Monetary Union", International Finance, 8 (1), 119-137

Sunirand, P. (2003), "The role of bank capital and the transmission mechanism of monetary policy”, Financial Markets Group Discussion Papers, No. 433.

Townsend, R. (1979), "Optimal contracts and competitive markets with costly state verification", Journal of Economic Theory, 21, 265-293

Van den Heuvel, S. (2006), "The bank capital channel of monetary policy", 2006 Meeting Papers, Society for Economic Dynamics, No. 512. 
Appendix 1. The main structure of the model for each member country

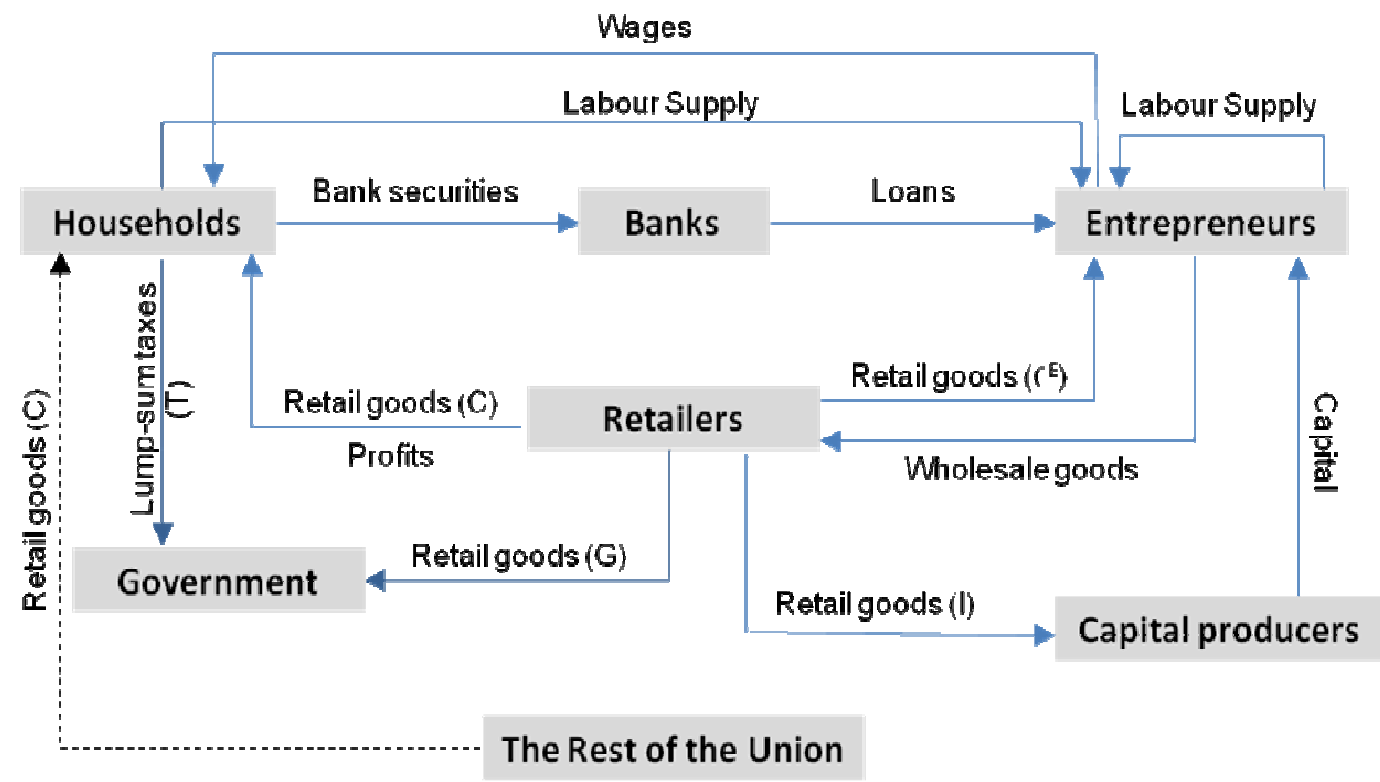

Appendix 2. The case of France and Italy during the subprime mortgage crisis (Source: IMF)
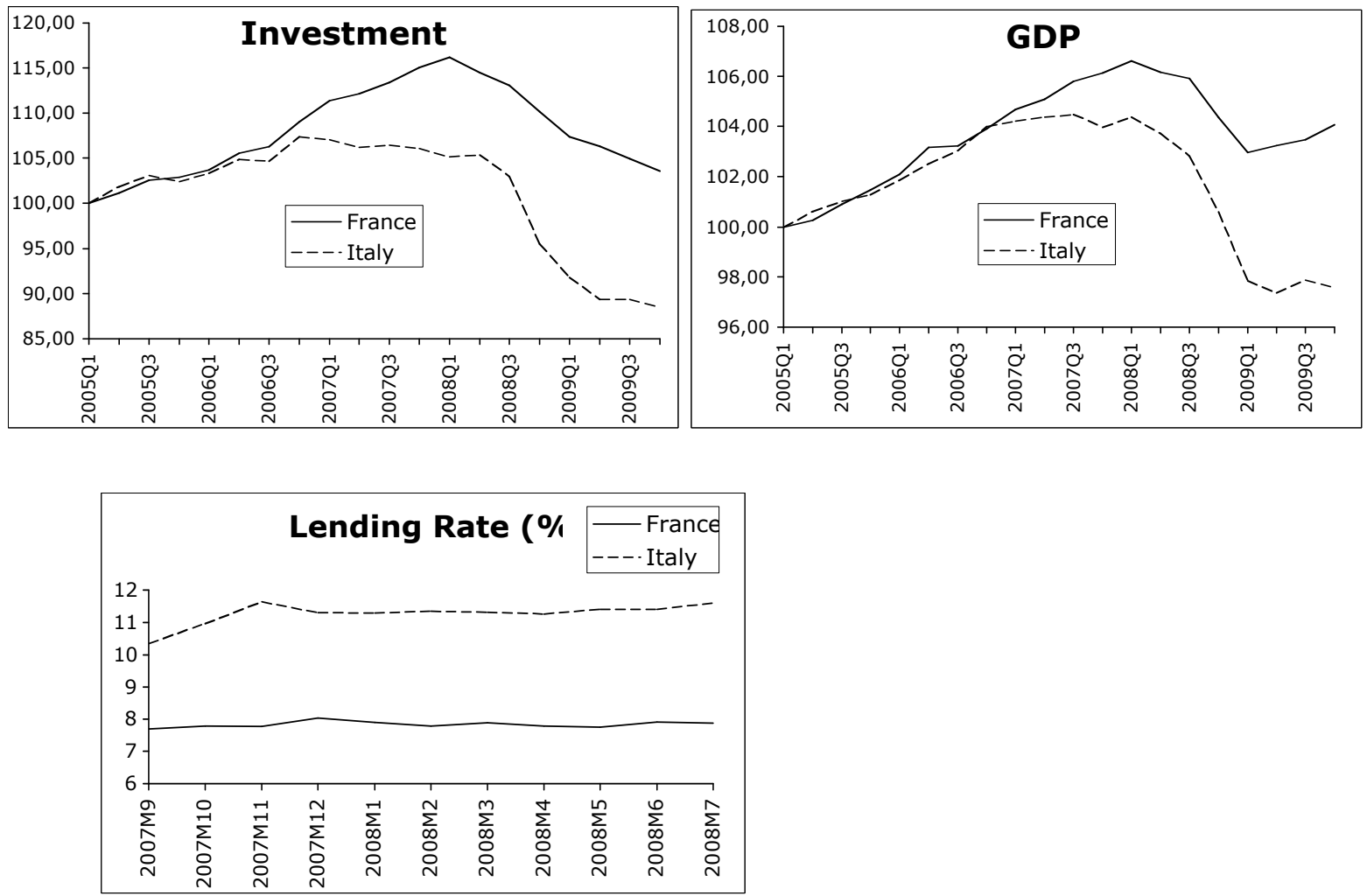
Appendix 3. Calibration of the DSGE model

\begin{tabular}{|c|c|c|c|}
\hline Description & Parameter & $\begin{array}{l}\text { Value } \\
\text { country } 1\end{array}$ & $\begin{array}{l}\text { Value } \\
\text { country } 2\end{array}$ \\
\hline Intertemporal elasticity of substitution & $\sigma_{c}$ & 0.75 & 0.75 \\
\hline Elasticity of labour disutility & $\sigma_{h}$ & 0.32 & 0.32 \\
\hline Subjective discount factor & $\beta$ & 0.99 & 0.99 \\
\hline Part of retailers with unchanged prices on the period & $\varsigma$ & 0.75 & 0.75 \\
\hline Capital contribution to GDP & $\alpha$ & 0.35 & 0.35 \\
\hline Part of entrepreneurial labour in total labour & $1-\Omega$ & 0.01 & 0.01 \\
\hline Part of households labour in total labour & $\Omega$ & 0.99 & 0.99 \\
\hline Depreciation rate for capital & $\delta$ & 0.03 & 0.03 \\
\hline Internal capital adjustment costs parameter & $\phi$ & 10 & 10 \\
\hline Part of inside capital transferts to survival banks & $t^{B}$ & 0.001 & 0.001 \\
\hline Banks external finance premium elasticity & $\psi_{B}^{s}$ & 0.002 & 0.001 \\
\hline Firms external finance premium elasticity & $\psi_{F}^{s}$ & 0.025 & 0.025 \\
\hline Part of foreign goods in national consumption & $1-\gamma$ & 0.2 & 0.2 \\
\hline \multicolumn{4}{|l|}{ Steady State: Exogenous fixed values } \\
\hline Real marginal cost & $\rho$ & $1 / 1.1$ & $1 / 1.1$ \\
\hline Banks inside capital/ loans ratio & $N B / B$ & 0.15 & 0.2 \\
\hline Firms net wealth/ capital ratio & $N F / K$ & 0.4 & 0.4 \\
\hline Public expenditures/GDP ratio & $G / P I B$ & 0.16 & 0.16 \\
\hline Firms probability of default & $F\left(\bar{\omega}^{F}\right)$ & 0.03 & 0.03 \\
\hline Banks probability of default & $F\left(\bar{\omega}^{B}\right)$ & 0.07 & 0.07 \\
\hline $\begin{array}{l}\text { Average external finance premium for firms } \\
\text { (in annual basis) }\end{array}$ & $r^{K}-r^{f}$ & 0.02 & 0.02 \\
\hline \multicolumn{4}{|l|}{ Steady State: Calculated values } \\
\hline Auditing cost for banks & $\mu^{B}$ & 0.018 & 0.077 \\
\hline Auditing cost for households & $\mu^{A}$ & 0.807 & 0.545 \\
\hline Variance for the $\omega$ distribution & $\sigma$ & 0.2531 & 0.2531 \\
\hline$\omega$ threshold value for banks & $\bar{\omega}^{B}$ & 0.52 & 0.52 \\
\hline$\omega$ threshold value for firms & $\bar{\omega}^{F}$ & 0.6016 & 0.6016 \\
\hline Banks probability to leave the market & $1-\gamma^{B}$ & 0.01 & 0.01 \\
\hline Firms probability to leave the market & $1-\gamma^{F}$ & 0.017 & 0.017 \\
\hline Capital/GDP ratio & $K / Y$ & 7.0549 & 7.0549 \\
\hline Investment/ GDP ratio & $I / Y$ & 0.2116 & 0.2116 \\
\hline Banks consumption expenses/GDP & $C B / Y$ & 0.006 & 0.008 \\
\hline Firms consumption expenses/GDP & $C F / Y$ & 0.048 & 0.048 \\
\hline Households consumption expenses/GDP & $C / Y$ & 0.5735 & 0.5501 \\
\hline Total consumption expenses/GDP & $(C+C F+C B) / Y$ & 0.628 & 0.628 \\
\hline
\end{tabular}

